\title{
PENGABDIAN TERHADAP MASYARAKAT PADA BALITA MENDERITA ISPA MENGGUNAKAN TERAPI KOMPLEMENTER FISIOTRAPI DADA
}

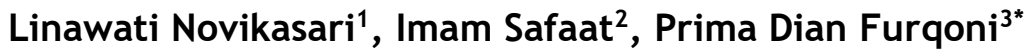 \\ 1,2,3Universitas Malahayati
}

Email Korespondensi: primadianfurqoni@malahayati.ac.id

\begin{abstract}
ABSTRAK
Infeksi pernafasan merupakan penyakit akut yang paling banyak terjadi pada anak-anak. Tujuan Deskripsi hasil Asuhan Keperawatan Komprehenshif Pada Balita Dengan Masalah Keperawatan Gangguan Bersih Jalan Nafas (Ispa) MenggunakanTerapi Komplementer menggunakan fisiotrapy dada di desa banjit kecamatan banjit kabupaten waykanan Tahun 2020 Metode yang di lakukan dengan Intervensi Fisioterapi dada yang di lakukan adalah Mengatur posisi pasien (tengkurap di pangkuan) dengan wajah menghadap ke baskom yang berisi air panas. Menutup kepala pasien dengan handuk kecil agar aroma minya kayu putih dapat terhidup dengan benar. Lakukan clapping dengan cara tangan perawat menepuk punggung secara bergantian. Lakukan perkusi selama 1-2 menit. Lakukan vibrasi pada punggung pasien saat dahak keluar, Pada anak -anak, cukup 3 sampai 5 menit. Lakukan sekitar 4- 5 kali. kemudian bersihkan area mulut dan hidung pasien dengan tissue. Berikan minyak kayu putih pada punggung dan telapak kaki pasien. Hasil Fisioterapi dada yang di lakukan pada ke dua anak di dapatkan hasil yang dapat mengurangi lendir dijalan nafas. Sehingga kedua anak merasakan lebih lega serta dapat tidur lebih tenang. Dari 3 hari pelaksanaan kedua anak dalam intervensi didapatkan hasil yang sama yakni pengeluaran dan perubahan membaik pada hari pertama, hal ini di karenakan usia anak tidak jauh berbeda, kemudian pelaksanaan diikuti anak dengan baik.
\end{abstract}

Kata Kunci: Balita, ISPA, Terapi

\begin{abstract}
Respiratory infections are the most common acute illness in children. Objective Description of the results of comprehensive nursing care in toddlers with nursing problems Clean Airway Disorders (Ispa) Using Complementary Therapy using chest physiotrapy in the banjit village banjit sub-district of Waykanan in 2020 Methods to be performed with the Intervention of Chest Physiotherapy that is done is to regulate the position of the patient (prone in chest) in the banjit village lap) with face facing the basin filled with hot water. Cover the patient's head with a small towel so that the scent of eucalyptus can be alive properly. Clapping the nurse's hands alternately patting her back. Perform percussion for 1-2 minutes. Perform vibrations on the patient's back when sputum is out, in children, just 3 to 5 minutes. Do it about 4- 5 times. then clean the patient's mouth and nose area with tissue. Apply eucalyptus oil to the patient's back and feet. Results Chest physiotherapy done on the two children get results that can reduce mucus on the way of breath. So that both children feel more relieved and can sleep more quietly. From 3 days the implementation of the two children in
\end{abstract}


the intervention obtained the same results namely expenditure and changes improved on the first day, this is because the age of the child was not much different, then the implementation was followed by the child well.

Keywords: Toddlers, ISPA, Therapy

\section{PENDAHULUAN}

Penyakit ISPA sering terjadi pada anak Balita, karena sistem pertahanan tubuh anak masih rendah. Kejadian batuk pilek pada balita di Indonesia diperkirakan 3 sampai 6 kali pertahun, yang berarti seorang balita rata-rata mendapat serangan batuk-pilek 3 sampai 6 kali setahun. Penyakit ISPA dapat ditularkan melalui air ludah, bersin, udara pernapasan yang mengandung kuman yang terhirup oleh orang sehat kesaluran pernapasannya. Infeksi saluran pernapasan bagian atas terutama yang disebabkan oleh virus, sering terjadi pada semua golongan umur, tetapi ISPA yang berlanjut menjadi Pneumonia sering terjadi pada anak kecil terutama apabila terdapat giz i kurang dan dikombinasi dengan keadaan lingkungan yang tidak hygiene (Wong, 2011).

Berbagai faktor risiko yang meningkatkan kejadian, beratnya penyakit dan kematian karena ISPA, yaitu status gizi (gizi kurang dan gizi buruk memperbesar risiko), pemberian ASI (ASI eksklusif mengurangi risiko), suplementasi vitamin A (mengurangi risiko), suplementasi zinc (mengurangi risiko), bayi berat badan lahir rendah (meningkatkan risiko), vaksinasi (mengurangi risiko), dan polusi udara dalam kamar terutama asap rokok dan asap bakaran dari dapur (meningkatkan risiko) (Kartika, 2017).

Strategi untuk pengobatan, pencegahan dan melindungi anak dari ISPA adalah dengan memperbaiki manajemen kasus pada semua tingkatan, vaksinasi, pencegahan dan manajemen infeksi HIV, dan memperbaiki gizi anak. Pemberian antibiotika segera pada anak yang terinfeksi pneumonia dapat mencegah kematian. UNICEF dan WHO telah mengembangkan pedoman untuk diagnosis dan pengobatan pneumonia di komunitas untuk negara berkembang yang telah terbukti baik, dapat diterima dan tepat sasaran. Antibiotika yang dianjurkan diberikan untuk pengobatan pneumonia di negara berkembang adalah kotrimoksasol dan amoksisilin. (Kemenkes RI, 2013).

Berdasarkan hasil survey awal yang, Setelah dilakukan wawancara, salah satu orang tua pasien mengatakan kondisi anaknya mengalami batuk- batuk, pilek, demam dan disertai sesak nafas. Gejala awal yang dirasakan pasien yaitu bersin- bersin dan batuk. Disini orang tua hanya menganggap anaknya demam biasa. Saat ditanya orang tua mengatakan, kebiasaan orang tua merokok di dalam rumah atau di dekat balita itu sendiri. Oleh karena itu, peran perawat sangat diperlukan untuk memberitahu dan mengajarkan kepada keluarga agar keluarga bisa menghindari faktor- faktor resiko tersebut dan mampu untuk merawat balitanya yang sakit. Pada anak balita, gejala infeksi pernapasan bawah biasanya lebih parah dibandingkan dengan penyakit pernapasan atas dan dapat mencakup gejala gangguan respiratori yaitu batuk, disertai produksi secret berlebih sesak napas, retraksi dada, takipnea, dan lainlain. Hal ini membutuhkan perhatian khusus oleh pemerintahan guna menurunkan angka kematian anak. Kesiapan pemerintah dan instansi terkait seperti tenaga kesehatan baik ditingkat pusat, provinsi ataupun kota dan kabupaten sangat berperan penting dalam meminimalkan angka kejadian ISPA. Seperti kesiapan pihak tenaga kesehatan terhadap pelayanan kesehatan, kesiapan petugas kesehatan dalam 
meningkatkan pengetahuan masyarakat terhadap pneumonia, status gizi, lingkungan yang baik, cakupan imunisasi, asi ekslusif dan meningkatkan upaya manajemen tatalaksana pneumonia bagaimana perilaku masyarakat dalam pencarian pengobatan. Pada akhirnya diharapkan upaya pengendalian penyakit ISPA dapat dilaksanakan dengan optimal sehingga angka kematian ini dapat diturunkan (Kemenkes RI, 2017).

Menurut Libianigsih (2014) Setelah dilakukan terapi sebanyak enam kali didapatkan hasil adanya peningkatan ekspansi sangkar thorax kearah yang baik untuk melakukan proses inspirasi dan ekspirasi maksimum dan normal yaitu awal terapi (T1):2 menjadi 3 pada (T6) pada axis axilla, (T1):2 menjadi 3 pada (T6) pada axis ICS 4, (T1):2 menjadi 3 pada (T6) pada axis proc. Xypoideus. Frekuensi pernafasan yang menurun yang mengarah pada batas normal diukur dengan inspeksi yaitu awal terapi (T1):46 x/menit menjadi $40 \mathrm{x} /$ menit pada (T6). Kesimpulan: Infra merah (IR) dan chest therapy dapat meningkatkan ekspansi sangkar thorax dan menurunkan frekuensi pernafasan Fisioterapi dengan mengunakan pemberian infra merah (IR) dan chest therapy terhadap ISPA yang dapat bermanfaat untuk mengurangi sesak nafas, membantu pengeluaran sputum, ekspansi thoraks, dan rileksasi otot-otot pernafasan. Chest therapy merupakan upaya untuk membersihkan jalan nafas dari mucus dan sekresi yang berlebih. Untuk anak dengan batuk, pileg diberikan teknik chest therapy dengan tujuan untuk membersihkan saluran pernafasan dan memperbaiki pertukaran udara (Libianingsih, 2014).

\section{MASALAH}

Berdasarkan hasil survey awal yang, Setelah dilakukan wawancara, salah satu orang tua pasien mengatakan kondisi anaknya mengalami batuk- batuk, pilek, demam dan disertai sesak nafas. Gejala awal yang dirasakan pasien yaitu bersinbersin dan batuk. Disini orang tua hanya menganggap anaknya demam biasa. Saat ditanya orang tua mengatakan, kebiasaan orang tua merokok di dalam rumah atau di dekat balita itu sendiri. Oleh karena itu, peran perawat sangat diperlukan untuk memberitahu dan mengajarkan kepada keluarga agar keluarga bisa menghindari faktor- faktor resiko tersebut dan mampu untuk merawat balitanya yang sakit. Berikut peta lokasi kegiatan:

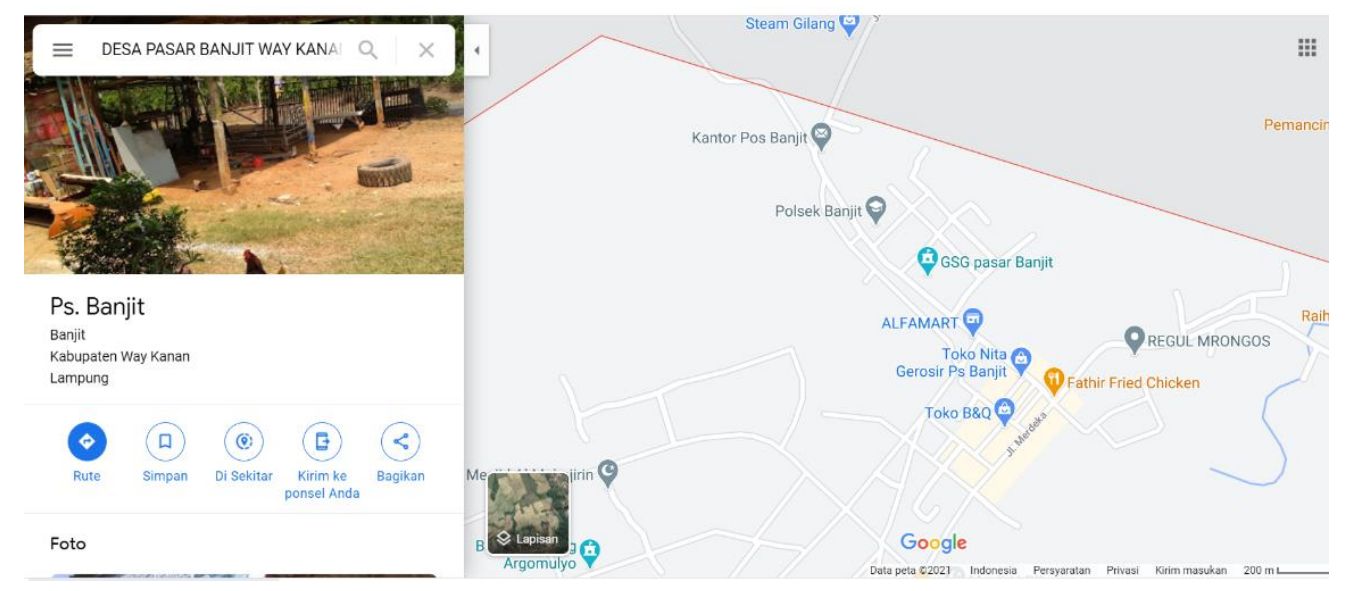

Gambar 2.1 Peta Lokasi Kegiatan 


\section{METODE}

Fisioterapi dada yang di lakukan adalah Mengatur posisi pasien (tengkurap di pangkuan) dengan wajah menghadap ke baskom yang berisi air panas. Menutup kepala pasien dengan handuk kecil agar aroma minya kayu putih dapat terhidup dengan benar. Lakukan clapping dengan cara tangan perawat menepuk punggung secara bergantian. Lakukan perkusi selama 1-2 menit. Lakukan vibrasi pada punggung pasien saat dahak keluar, Pada anak anak, cukup 3 sampai 5 menit. Lakukan sekitar 4 - 5 kali. kemudian bersihkan area mulut dan hidung pasien dengan tissue. Berikan minyak kayu putih pada punggung dan telapak kaki pasien.

\section{HASIL PENELITIAN DAN PEMBAHASAN}

\section{Pengkajian}

Data subyektif ibu mengatakan keadaan An. J umur 2 tahun, nafsu makan anak menurun, batuk dan pilek. Pada data obyektif keadaan umum baik kesadaran composmentis, pemeriksaan suhu $38,8^{\circ} \mathrm{C}$, tenggorokan berwarna merah, pernafasan $39 x /$ menit, anak rewel , pada hidung terdapat cairan jernih dan encer kulit bagian luar tampak kemerahan, pernafasan sesak terdengar bunyi Ronchi, conjungtiva merah muda. Pada kasus kedua menurut kasus An. A umur 10 bulan dengan ISPA sedang pada data subyektif ibu mengatakan keadaan An. A umur 10 bulan, nafsu makan anak menurun, batuk dan pilek disertai demam . Pada data obyektif keadaan umum baik, kesadaran composmentis pemeriksaan suhu $37,6^{\circ} \mathrm{C}$. tenggorokan berwarna merah, pernafasan $58 \mathrm{x} /$ menit, pada hidung terdapat cairan jernih dan encer, batuk terus menerus, pernafasan sesak terdengar bunyi Ronchi sehingga anak rewel dan tidak nafsu makan.

Fisioterapi dengan mengunakan pemberian infra merah (IR) dan chest therapy terhadap ISPA yang dapat bermanfaat untuk mengurangi sesak nafas, membantu pengeluaran sputum, ekspansi thoraks, dan rileksasi otot-otot pernafasan. Chest therapy merupakan upaya untuk membersihkan jalan nafas dari mucus dan sekresi yang berlebih. Untuk anak dengan batuk, pileg diberikan teknik chest therapy dengan tujuan untuk membersihkan saluran pernafasan dan memperbaiki pertukaran udara (Libianingsih, 2014).

Intervensi Fisioterapi dada yang di lakukan adalah Mengatur posisi pasien (tengkurap di pangkuan) dengan wajah menghadap ke baskom yang berisi air panas. Menutup kepala pasien dengan handuk kecil agar aroma minya kayu putih dapat terhidup dengan benar. Lakukan clapping dengan cara tangan perawat menepuk punggung secara bergantian. Lakukan perkusi selama 1-2 menit. Lakukan vibrasi pada punggung pasien saat dahak keluar, Pada anak -anak, cukup 3 sampai 5 menit. Lakukan sekitar 4- 5 kali. kemudian bersihkan area mulut dan hidung pasien dengan tissue. Berikan minyak kayu putih pada punggung dan telapak kaki pasien.

Pada pasien ke -2 Implementasi pada hari pertama : mengkaji frekuensi pernapasan, melakukan inhalasi uap manual, memberikan posisi semi fowler. Respon subjektif : ibu klien mengatakan anaknya batuk pilek sudah 3 hari. Respon objektif : RR : $39 x / m$, ada penumpukan sputum, suara pernapasan ronchi, melakukan dan mengajarkan inhalasi uap dan semi fowler.

Hasil evaluasi selama 3 hari dilakukannya asuhan keperawatan pada kedua pasien dengan ketidakefektifan bersihan jalan napas berhubungan penumpukan sekret. Didapat kan hasil pada hari ketiga S: Ibu pasien 
mengatakan dahak yang dikeluarkan sudah tidak ada, ada O: Suara pernapasan ronchi sudah tidak ada masih ada, respirai rate $35 \mathrm{x} / \mathrm{m}$, sputum masih ada A: Masalah sudah teratasi P: Intervensi di hentikan. Kriteria hasil yang di capai jalan napas yang paten (frekuensi dalam rentang normal), dan mampu menidentifikasi faktor penghambat jalan napas.

Fisioterapi dada yang di lakukan pada ke dua anak di dapatkan hasil yang dapat mengurangi lendir dijalan nafas. Sehingga kedua anak merasakan lebih lega serta dapat tidur lebih tenang. Dari 3 hari pelaksanaan kedua anak dalam intervensi didapatkan hasil yang sama yakni pengeluaran dan perubahan membaik pada hari pertama, hal ini di karenakan usia anak tidak jauh berbeda, kemudian pelaksanaan diikuti anak dengan baik.

\section{KESIMPULAN}

1. Dari hasil pengkajian didapatkan diklasifikasikan sebagai balita sakit ISPA. Dari data subyektif ibu mengatakan keadaan anaknya batuk, pilek, panas, nafsu makan menurun, dan rewel.

2. Dari hasil interpretasi data didapatkan diagnosa ISPA sedang, masalah yang muncul adalah batuk, pilek, panas dan rewel (Kebutuhan yang diperlukan adalah informasi tentang perawatan anak dengan ISPA

3. Perencanaan tindakan telah sesuai teori yaitu terapi non farmakologi yakni Fisioterapi dada.

4. Pelaksanaan tindakan dapat dilakukan dengan baik sesuai rencana yang telah disusun karena adanya dukungan keluarga.

5. Evaluasi dilakukan untuk mengetahui perkembangan balita, dan hasilnya keadaan umum baik, kesadaran composmentis, nafsu makan anak baik, pemeriksaan fisik dan TTV baik, dan anak dinyatakan sembuh.

\section{DAFTAR PUSTAKA}

Ariasti, D., (2014). Pengaruh Pemberian Fisioterapi Dada Terhadap Bersihan Jalan Nafas pada Pasien ISPA di Desa Pucung Erpmoko Wonogiri. Wonogiri :Kosma.

Brunnner \& Suddarth. (2002). Buku Ajar keperawatan Medikal Bedah. (ed. 8). Jakarta: EGC.

Depkes RI. (2011). Buku Bagan Manajemen Terpadu Balita Sakit (MTBS). Jakarta: Usaid.

Depkes RI. (2007). Pedoman Tatalaksana Pneumonia Balita,Dirjen PP \& PL.

Kementerian Kesehatan RI. (2013). Pedoman Pengendalian Infeksi Saluran Pernapasan Akut. Jakarta: Direktorat Jenderal pengendalian Penyakit dan Penyehatan.

Kementerian Kesehatan RI. (2018). Riset Kesehatan Dasar 2018. Jakarta: Badan Penelitian dan Pengembangan Kesehatan.

Hidayat, Aziz Alimul. (2009). Metode Penelitian Keperawatan dan Teknik Analisa Data. Jakarta: Salemba Medika.

Kementrian Kesehatan RI. (2012). Profil Data Kesehatan Indonesia. Jakarta: Kementrian Kesehatan RI.

Libianingsih, R. (2014). Penatalaksanaan Fisioterapi Pada Kondisi Infeksi Saluran Pernafasan Akut (Ispa) Di Rsud Panembahan Senopati Bantul (Doctoral dissertation, Universitas Muhammadiyah Surakarta. 
Maidartati. (2014). Pngaruh Fisioterapi Dada. Terhadap Bersihan Jalan Nafas pada Anak Usia 1-5 Tahun yang Mengalami Gangguan.

Miharti, S. (2017). Penerapan Fisioterapi Dada (Clapping) Untuk Mengeluarkan Dahak Pada Anak Dengan Infeksi Saluran Pernapasan Akut (Ispa) Di Ruang Melati Rsud Dr. Soedirman. Kebumen (Doctoral dissertation, STIKES MUHAMMADIYAH GOMBONG).

Muttaqin, Arif. (2008). Buku Ajar Asuhan Kep erawatan Klien dengan Gan gguan Sistem Pernapasan. Jakarta : Salemba Medika.

Ngastiyah. (2005). Perawatan Anak Sakit edisi 2. Jakarta: EGC.

Price and Wilson. (2005). Konsep Klinis Proses-Proses Penyakit Edisi 6. Vol.2. Jakarta : EGC.

WHO. (2007). Pencegahan dan Pengendalian Infeksi Saluran Pernapasan Akut (ISPA) Yang Cenderung Menjadi Epidemi dan Pandemi di Fasilitas Pelayanan Kesehatan. Pedoman Interim WHO. Alih Bahasa: Trust Indonesia. Jakarta.

Wong, D, dkk. (2009). Buku Ajar Keperawatan Pediatrik. Volume 1. Penerbit. Buku Kedokteran EGC : Jakarta 